\title{
INSANITY AS A DEFENSE TO THE CIVIL FRAUD PENALTY*
}

\author{
KENNETH G. ANDERSON†
}

I

INTRODUCTION

\begin{abstract}
A NECESSARY matter of inquiry in any civil fraud case, arising under the Internal Revenue Code of 1954, is whether the taxpayer has harboured a fraudulent intent to evade and defeat a tax which he knows and believes to be due and owing. ${ }^{1}$ In a recent decision, Emanuel Hollman, ${ }^{2}$ the Tax Court has held there to be no such fraudulent intent where the taxpayer raised the defense of insanity. That recent decision, by reason of its possible significant implications, prompts consideration of the relationship of the condition of insanity or incompetency of the taxpayer to matters of federal taxation in general and to the civil fraud penalty in particular.

The purpose of this article is to discuss some aspects of the defense of insanity to the assertion of the civil fraud penalty, in a case docketed in the Tax Court of the United States.
\end{abstract}

\section{II}

\section{Some Basic Considerations and Definitions}

\section{A. The Fraud Case in the Tax Court}

After administrative investigation and consideration of the potential fraud case where no agreement with respect to imposition or removal of the civil fraud penalty is reached by the Internal Revenue Service and the taxpayer, the Commissioner of Internal Revenue, through his delegate, may issue a statutory notice of deficiency to the taxpayer. $^{3}$ In this notice of deficiency, the Commissioner may de-

* The views expressed are the author's and should not be considered as being the opinion of the Treasury Department, the Internal Revenue Service, or the Chicf Counsel's Office.

† A.B. 1953, University of North Carolina; J.D. 1958, George Washington University; Attorney, Office of Chief Counsel, Atlanta Region, Internal Revenue Service.

1 William W. Kellett, 5 T.C. 608 (1945); M. Rea Gano, 19 B.T.A. 518 (1930): 10 Mertens, LAw OF FEDERAL IncoMe TAXATION $\$ 55.10$.

38 T.C. No. 28 (1962), on rehearing, P-H 1962 Tax Ct. Mcmo 11 62,236 (1962).

3 INT. REv. CODE OF 1954, \$6212. 
termine that there is due from the taxpayer a deficiency in tax, together with a fifty per cent addition to the tax for fraud. 4 Within ninety days from the issuance of the statutory notice of deficiency, the taxpayer may petition the Tax Court of the United States for redetermination of the proposed deficiency in tax, and for redetermination of the proposed addition to the tax for fraud. ${ }^{5}$

The statutory authority relied upon by the Commissioner for assertion of the addition to the tax for fraud is section 6653 (b) of the Internal Revenue Code of 1954. Under that provision, the severe sanction of the addition to the tax of fifty per cent of any underpayment is imposed upon the taxpayer where "any part of the underpayment ... of tax required to be shown on a return is due to fraud ...." This civil sanction is obviously quite severe. Its importance is magnified by consideration of the rule that the fraud penalty may be imposed where the underpayment is due, in whole or in part, to fraud. Thus, where fraud exists, the penalty attaches not merely to the fraudulent item but to the entire underpayment. ${ }^{6}$ The basic purpose of the civil fraud penalty is remedial-to protect the revenue and to compensate the Government for the expense of investigation and prosecution of the fraud case. ${ }^{7}$

In the docketed tax court case where the determination of fraud is at issue, the burden of proof with respect to fraud is placed upon the Commissioner by statute and by the rules of practice of the Tax Court. ${ }^{8}$ The standard of proof required of the Commissioner is that the taxpayer's fraud must be proven to the satisfaction of the court by "clear and convincing evidence." The litigated cases which are legion, demonstrate that this is a burden not be lightly regarded.10 A leading authority on the subject of fraud, both criminal and civil, has succinctly described this formidable task as follows:

It is an illusion that there is any clear demarcation between a set of facts which would justify only the imposition of the $50 \%$ civil fraud penalty, and one which would call for tax evasion prosecution. Statutorily, the requirement for the civil penalty is simply 'fraud,' while for criminal tax

\footnotetext{
"See, e.g., Kiker v. Commissioner, 218 F.2d 389 (4th Cir. 1955).

- INT. REv. CODE OF 1954, §6213.

- Arlette Coat Co., 14 T.C. 751 (1950); Maitland A. Wilson, 7 T.C. 395 (1946).

"Helvering v. Mitchell, 303 U.S. 391 (1938).

Int. Rev. Code of 1954, §7454 (a); Tax Court R. Prac. 32.

- Estate of Helene Simmons, 26 T.C. 409, 426 (1956).

20 See 10 MERtens, Law of Federal Income Taxation $\$ 55.09$.
} 
evasion, it is 'wilfully attempts in any manner to evade or defeat any tax.'

...

As a matter of actual experience, it can be safely stated that given identical sets of facts, it would often be more difficult for the Commissioner successfully to sustain an asserted civil fraud penalty in the Tax Court than it would be for the United States Attorney to obtain a conviction in a criminal evasion case before a jury. ${ }^{11}$

In relating the defense of insanity to the assertion of such fraud penalty, it would be convenient to provide a capsule definition of fraud, but such a definition would be illusory. The potential sources of fraud in tax cases are virtually without limit; the ingenuity of the taxpayers compounded by the complexity of the statutes involved insure this. Not only are the matters of "fraud" without limit and not susceptible to precise legal definition, but to attempt to be too specific would open the door to calculated evasion by quibbling over the terms used and their precise legal import.12 However, it is clear that one of the elements of fraud which must be shown by the Commissioner to sustain his determination in court is the taxpayer's fraudulent intent.

\section{B. Intent, an Element of Fraud}

There is one essential element which is the very heart of the fraud issue, namely, "the intent to defraud the Government by calculated tax evasion."13 It is in considering this element of fraud, which is the actual "intent to evade," that the plea of insanity or incompetency becomes relevant. From a definitional standpoint, what is the nature of the requisite "intent to evade?" In any matter so essentially factual as the matter of fraud, any attempt at precise definition will provoke dissent. However, one favored statement of the nature of the intent required is as follows:

The term fraud means actual intentional wrongdoing, and the intent required is the specific purpose to evade a tax believed to be owing. Fraud implies bad faith, intentional wrongdoing and a sinister motive. It is never imputed or presumed .... Generally speaking, there must be an intent to mislead or defraud before the penalty can be imposed. The first and basic element in fraud is a fraudulent intent-a state of mind

\footnotetext{
${ }^{11}$ See Balter, A Ten Year Review of Fraud Prosecutions, NYU 19Th INST. ON FED. TAX 1125, 1135 (1961).

19 10 MERTENS, LAW OF FEderal InCOME TAXation $\$ 55.10$.

${ }^{13}$ E. S. Iley, 19 T.C. 631,685 (1952).
} 
which, if translated into action is calculated to cheat or deceive the Government. The state of mind may be express or implicit in action, but its existence must be proved by clear and convincing evidence. The intent required is a specific intent . . . 14

Perhaps the immediate reaction is that presence of the condition of insanity would automatically preclude assertion of the civil fraud penalty during the administrative stages of the case, for how could such fraudulent intent, as defined above, be harbored by a clearly insane person? Or stated another way, how could the defense of insanity ever be seriously raised in a case where the taxpayer has entered financial transactions of such complexity to lead to realization of income of such magnitude as to justify assertion of the fraud penalty? There is probably an initial reaction that such a defense could not be seriously advanced in any case of sufficient merit to survive the intensive administrative and pretrial review given any case where the civil fraud penalty has been asserted.15 The obvious case of insanity would clearly be so eliminated. However, there are many types of insanity, many borderline cases, and many grades of insanity. ${ }^{16}$ Moreover, in view of the widely expanding medicolegal concept of insanity, it is patent that such broad conclusion is erroneous. ${ }^{17}$ The paucity of decided cases in which this issue has been presented affords some support for the view that the defense is rarely litigated. However, the recent decision of the Tax Court in Emanuel Hollman, discussed in detail below, clearly reveals that such initial reaction, while logical, is not necessarily correct. That recent Tax Court decision prompts some consideration of the various types of insanity, legal capacity to act, and the relationship of insanity to matters of federal taxation.

\section{III}

\section{Insanity as It Relates to the Intent to Ayom Taxation}

\section{A. Forms of Insanity and Civil Incapacity}

There are many forms of medical insanity or incompetency, of varying degrees of severity, ${ }^{18}$ and other conditions which may affect

\footnotetext{
16 10 Mertens, LAw of Federal Income TAXation $\$ 55.10$. See also William W. Kellett, 5 T.C. 608 (1945); M. Rea Gano, 19 B.T.A. 518 (1930).

${ }^{16}$ See Internal Revenue Service: Organization and Functions, $\S 1113.73,1114.9$, 1116.2, 1118.6, 21 Fed. Reg. 10418 (1956); 10 MERTENs, LAw of FEDERAL INCONE TAXATION $\$ 55.15$.

10 See notes 17 and 18 infra.

17 See Lindman \& MacIntyre, The Mentally Disabled and the Law (1961).

${ }^{18}$ E.g., Delerium, a state of mind where the mind acts without direction by the
} 
one's reason which do not constitute recognized insanity or incompetency. ${ }^{19}$ This conditon of one's mind may affect one's capacity to do or perform an act recognized as having legal significance. Legal insanity, which exonerates one from blame for crime or renders one incapable from civil action, is a mental deficiency with reference to the particular act in question; it does not necessarily require a general incapacity. Therefore, there can be no general definition of legal insanity. It is a condition which must be noted witl reference to each class of actions to which it is applied. ${ }^{20}$

The general principle, governing the civil incapacity of a person of unsound mind is that any civil act is invalid or voidable if the actor was, at the time, laboring under such mental defect as to render him incapable of performing the act in question rationally and without detriment to any person affected thereby. ${ }^{21}$ There is further

power of volition; Delerium tremens, insanity produced by the collapse of the human system as a result of habitual drunkenness; Delusion, (a) belief in tbings impossible according to human experience and (b) belief in things possible, but so improbable that no person of sound mind would entertain such belief; Emotional insanity, one in possession of his ordinary faculties, without mental disease, who gives away to his passions to such an extent as to become a temporary maniac; Feeble-mindedness, incomplete development of mind of such degree or kind as to render one incapable of adjusting to his social environment without care, supervision or control; Hallucination, false perception of objects which do not, in fact, make an impression on the external senses; Homicidal mania, the morbid and uncontrolled appetite for mankilling; Hypnotism, induced somnambulism; Idiocy, the condition of one who from birth has lacked reason; Imbecility, a more general term applied to many conditions and forms of mental weakness; Irresistible or uncontrollable impulse, impulsive insanity (not the situation where one in possession of reason is impelled by passion to commission of repulsive acts); Kleptomania, a morbid propensity to steal, whether conscious or unconscious; Lunacy, an impairment of one or more mental facultics accompanied by a defect in the power of comparison; Monomaniac, one insane on a particular subject but sane on all other matters; Moral insanity, inability to distinguish between right and wrong; non compos mentis, a person entirely destitute of memory and understanding; Paranoia, delusional insanity or monomania; Partial insanity, a clouded or weakened mind, not incapable of memory, reason or judgment; Schizophrenia, a loss of contact with environment and disintegration of the personality; Temporary insanity, temporary derangement resulting from a transient condition, such as introxication. 29 AM. Jur. Insane Persons $\$ 3$ (1960).

${ }^{10}$ E.g., Deafness, dumbness, blindness, accident, disease, bad judgment, inexperience, susceptibility, eccentricities, particular beliefs, prejudices, and habitual drunkenness, 29 AM. JUR. Insane Persons $\$ \$ 4.8$ (1960).

${ }^{20} 1$ Bouv. Law Dicr. 1589 (1914).

a1 Thus, e.g., where an ordinary matter of contract is in question, the inquiry would be to determine whether the defect precluded rational assent to the contract, be it marriage, partnership or sale; and as to testamentary capacity, whether the defect precluded the testator from knowing the nature and extent of his property, to be aware of the natural objects of his bounty, and to appreciate the effect of tbe disposition made by him. 1 Bouv. LAW Dict. 1598 (1914); 29 AM. JUR. Insane Persons $\$ 81$ (1960). To the contrary, it is well settled that an incompetent, at common law, is liable for an injury caused by his tortious act committed where insane, provided that malice or 
authority, however, which indicates that, where intent is a necessary element of the civil action in question, mental incapacity to harbour such requisite intent will absolve the actor from civil liability. Thus, where malice is an element of libel or slander, or of malicious prosecution, ${ }^{22}$ or in a tort suit where exemplary or punitive damages are at issue, ${ }^{23}$ most jurisdictions will not impose civil liability upon an actor of unsound mind.24 Similarly, in the case of an action for fraud or deceit where intent is an element of the action, the majority view is that the insane person may not be held for damages in an action for fraud or deceit based upon intent. ${ }^{25}$

\section{B. The Test Applicable in Matters of Civil Taxation}

In matters of federal taxation such as determining the realization of income or the deductibility of losses or expenditures, knowledge, intent, insanity or incompetence of the taxpayer should ordinarily be collateral to the question presented. As succinctly put by the Court of Appeals for the Second Circuit: "Save in those instances where the statute itself turns on intent, a matter so real as taxation must depend on objective realities, not on the varying subjective beliefs of individual taxpayers."2o

Thus, an income tax return for the incompetent must be filed, and the incompetent and his committee are considered one taxable entity. ${ }^{27}$ In the case of the deductibility of interest, ${ }^{28}$ or in determining the time a loss has been sustained for federal tax purposes, ${ }^{29}$ application of an objective test provided by the statutes involved has led to rejection by the courts of the subjective views and state of mind of the taxpayer in reaching their result. ${ }^{30}$ It has long been the position of the Internal Revenue Service that a dividend check was income to an incompetent, even though he was legally in-

intent to injure is not a neccessary element of the tort. 29 AM. JUR. Insane Persons $\S 104(1960)$.

${ }^{22}$ AM. JUR. Insane Persons $\$ \S 106-07$ (1960).

${ }^{23}$ Wilson v. Walt, 138 Kan. 205, 25 P.2d 343 (1933); Phillips Committee v. Ward's

Adm'r., 241 Ky. 25, 43 S.W.2d 331 (1931); Beaubeauf v. Reed, 4 La. App. 344 (1926). ${ }^{26}$ Parke v. Dennard, 218 Ala. 209, 118 So. 396 (1928); Annot. 51 A.L.R. 833 (1927),

89 A.L.R. 476 (1934).

${ }^{25}$ Chaddock v. Chaddock, 130 Misc. 900, 226 N.Y.S. 152 (1927).

${ }^{20}$ Lynch v. Commissioner, 273 F.2d 867, 872 (2d Cir. 1959). See also MacRae v. Commissioner, 294 F.2d 56 (9th Cir. 1962).

${ }^{27}$ INT. Rev. Code of 1954, §6012 (b) (2); I.T. 3996, 1950-1 CuM. Bul. 130.

${ }^{28}$ INT, REv. CODE OF 1954, § 163.

${ }^{20}$ INT. Rev. CODE OF 1954, §165.

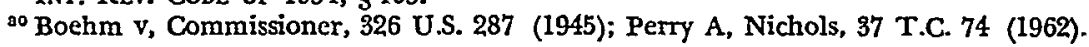


capable of endorsing or cashing such dividend check. ${ }^{31}$ Similarly, an incompetent's committee would be governed by the ordinary rules with respect to the exchanges of like property. ${ }^{32}$ It is also probably highly significant that incompetency does not appear to have been raised as a defense to taxability of gains even in those cases where insanity has been raised as a defense to fraud. ${ }^{33}$ However, an exception to this apparent general rule was presented in Juliette B. Andrews ${ }^{34}$ where the taxpayer, decreed incompetent, was held to have not realized gain in the year of sale on the unauthorized and improper sale of her securities by her chauffeur. She was held to have realized income only upon recovery of the proceeds of sale by her guardian.

On the other hand, incompetency of the taxpayer involved would appear to be relevant in determining subjectively, e.g., whether the taxpayer held the "view" requisite under the collapsible corporation provisions, ${ }^{35}$ whether he was competent to form the necessary donative intent to make a gift, ${ }^{36}$ whether a transfer was made in contemplation of death, ${ }^{37}$ whether the taxpayer was liable for the addition to the tax for failure to file a declaration of estimated tax or whether such failure to file was due to reasonable cause, ${ }^{38}$ and other

${ }^{31}$ I.T. 2072, III-2 CuM. BuIx. 76 (1924).

${ }^{32}$ Rev. Rul. 57-469, 1957-2 Cum. BuL. 521.

${ }^{33}$ See, e.g., Emanuel Hollman, 38 T.C. No. 28 (1962); United States v. Peelle Co., 137 F. Supp. 905 (E.D.N.Y. 1956); Fred M. Staudt, 22 P-H Tax Ct. Mem. 1262 (1953), aff'd per curiam, 216 F.2d 610 (4th Cir. 1954); Estate of Clinton H. Martin, 28 P.H Tax Ct. Mem. 88 (1959), aff'd per curiam, 272 F.2d 191 (2d Cir. 1959); Pasquale Colabella, 27 P-H Tax Ct. Mem. 608 (1958).

"11 P-H Tax Ct. Mem. 847 (1942).

${ }^{35}$ INT. REv. CODE of 1954, §341. See Braunstein v. Commissioner, 305 F.2d 949 (2d Cir. 1962).

${ }^{30}$ David L. Zips, 38 T.C. No. 62 (1962). In Zips, George Westinghouse had transferred cash and securities to Marie Zips without consideration. Subsequent to the date of such transfers, the transferor had been judicially determined to be of unsound mind at the time of the transfers and lacking the requisite mental capacity to effect a valid gift. In view of the transferor's lack of capacity to entertain the requircd donative intent, the Tax Court held the transfers to be not excludible from gross income as a gift under $\$ 102$ (a) of the Internal Revenue Code of 1954, but fully taxable to the transferee as ordinary income under $\$ 61$ (a). This, despite the fact that it had been judicially determined in litigation between the trustee for the transferor in a year subsequent to the transfer, that the transfers were not gifts between the partics and that the transferee did not acquire title thereto.

${ }^{87}$ INT. REv. CODE OF 1954, §2035.

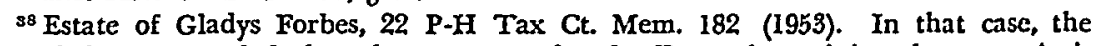
Commissioner conceded that there was no fraud. From the opinion, however, it is not apparent whether the concession was based upon the taxpayer's mental condition. 
analogous situations where the taxpayer's subjective processes were relevant.

In the foregoing situations, it would appear that insanity or incompetence of the taxpayer is generally collateral to the question presented, unless such mental condition directly affects the legal condition to taxability or deductibility.

\section{Insanity and the Decided Cases Prior to the Emanuel Hollman Case}

Fraud cases, which involve the element of intent, are another matter. It is patent that if fraudulent intent is a state of mind as the opinions indicate, insanity is relevant. In such cases, the real questions are: What is the test of insanity in determining whether the taxpayer has the capacity to form the requisite fraudulent intent, and, to what act does this test relate. That is to say, is it merely a question of general mental incapacity and lack of ability to formulate a fraudulent intent, or must the proof go further-must it show that the mental incapacity relates specifically to the federal income tax return.

Prior to the decision in Emanuel Hollman, the relatively few cases presented to the courts do not appear to have submitted for decision on good records, the issue of insanity. In those cases, evidence was presented to the effect that the taxpayer was under observation for his mental condition in a sanitarium during the taxable year involved; 39 that the taxpayer had suffered from mental disturbances, had undergone electric shock treatments for such condition, and had generally suffered some loss of memory or mental retrogression during the period at issue; 40 or that the taxpayer had arteriosclerosis and resultant bad judgment, upon which condition he had attempted to place blame for omission of income.41 Each contention that the taxpayer's mental condition would preclude a finding of fraud was rejected by the Tax Court. These cases produced no definite guidelines, either as to the tests of insanity applied or to the act to which such insanity must relate. However, some comments of the court do afford some limited indication of the

\footnotetext{
${ }^{30}$ Fred M. Staudt, 22 P-H Tax Ct. Mem. 1262 (1953), aff'd per curiam, 216 F.2d 610 (4th Cir. 1954).

${ }^{10}$ Pasquale Colabella, 27 P-H Tax Ct. Mem. 600 (1958).

"Estate of Clinton H. Martin, 28 P-H Tax Ct. Mem. 89 (1959), aff'd per curiam, 272 F.2d 191 (2d Cir. 1959).
} 
standards applied in those cases. Despite the fact that these com. ments were probably dicta, they are worth consideration in this facet of federal tax litigation so generally devoid of authority.

The Tax Court, in Fred $M$. Staudt, ${ }^{42}$ had observed as follows:

The petitioner places much reliance on his physical and mental illness and argues that at the time his original 1942 return was prepared, signed and filed, he relied on others for its preparation and that he was not aware that the return was in error. We are not convinced that the petitioner's illness had developed to such an extent by May 15, 1943, (the date the return was filed), that the petitioner was unaware of what he was doing .... (Emphasis added.)

In Estate of Clinton H. Martin, ${ }^{43}$ the court commented as follows:

It is noted that there is no contention that the doctor was non compos mentis in 1951 or did not know right from wrong or was not aware of the significance of his actions, but merely a contention that his judgment was impaired. In our opinion this argument is without merit. (Emphasis added.)

Perhaps the Fred M. Staudt and Estate of Clinton H. Martin cases indicate that some showing is necessary that the taxpayer does not know the consequences and significance of his acts and does not have the ability to distinguish between right and wrong in connection with his federal income tax returns. It would appear more conservative and more correct to conclude that no definitive guidelines as to the nature of the intent involved, or its relationship to civil fraud has been established in these cases. ${ }^{44}$

The Emanuel Hollman case however, appears to be more significant.

\section{The Emanuel Hollman Case}

Whether fortuitously or by design, the Tax Court may have provided some rather significant guidelines on the matter under

422 P-H Tax Ct. Mem. 1262, 1265 (1953), aff'd per curiam, 216 F.2d 610 (4th Cir. 1954). 1959).

428 P.H Tax Ct. Mem. 88, 91 (1959), aff'd per curiam, 272 F.2d 191 (2d Cir.

"4 While the cases of United States v. Peelle Company, 137 F. Supp. 905 (E.D.N.Y. 1956), and United States v. Peelle, 159 F. Supp. 45 (E.D.N.Y. 1958), are significant in establishing the importance of the use of lay witnesses on the fraud issuc, and in cstab. lishing that the condition of incompetence and the year of fraud must coincide, those cases add little to the consideration of the specific relationship between insanity and the intent to evade. 
consideration in Emanuel Hollman. In view of its possible significance, some detailed examination of that case is indicated.

Hollman, in many respects, appears to have presented a rather good case for the Government on the fraud issue. Briefly reviewed, the pertinent facts reveal that the taxpayer was well educated, having attended both college and law school. He was a certified public accountant and a licensed insurance broker-both of which activities were actively carried on during the taxable years. He engaged in many financial transactions of complexity during the taxable years. ${ }^{45}$ He showed alertness and astuteness on the witness stand at trial. Thus, in view of his education and profession and by reason of his actual employment, he was of the class most likely to have an awareness of tax matters. There was proof of a substantial and consistent omission or understatement of capital gains, dividends and interest. ${ }^{46}$ The amounts omitted exceeded his reported income.

$\begin{array}{lccc}\text { Year } & \text { Capital Gains } & \text { Dividends } & \text { Interest } \\ 1951 & \$ 4,841.01 & \$ 3,197.50 & \$ 666.31 \\ 1952 & 1,603.84 & 4,614.75 & 652.89 \\ 1953 & - & 4,548.31 & 650.00 \\ 1954 & 8,963.93 & 595.40 & 162.50 \\ 1955 & 8,436.10 & 4,500.80 & -\end{array}$

This pattern, and the relationship of income reported to the total realized, presented a recognized badge of fraud. ${ }^{47}$ Furthermore, when the taxpayer learned that the investigation was in process, he hastily filed an amended return for one of the taxable years-reporting sizeable amounts of previously unreported income. An inference most certainly could have been drawn from this overt act that the taxpayer was well aware he had intentionally omitted items from his return previously filed and in filing the amended return acted only in fear of being apprehended.

With respect to the taxpayer's defense of insanity, the Tax Court made the following findings of fact:

Petitioner had during taxable years, and still has severely impaired vision, caused by keratocotus. His vision without glasses was not better than 20/200 in either eye, and such vision could not be improved by glasses.

\footnotetext{
"Similar evidence led the District Court to reject the defense of insanity in Peelle and Peelle Company, supra note 44, despite the testimony by five psychiatrists in support of the taxpayer's contentions that he was incompetent.

10 Amounts omitted.

${ }^{17}$ Schwarzkopf v. Commissioner, 246 F.2d 731, 734 (3d Cir. 1957); Baumgardner v. Commissioner, 251 F.2d 311 (9th Cir. 1957).
} 
It could be improved by a special type of contact lenses to 20/60 in the right eye and 20/70 in the left eye. With the aid of the contact lenses he could read and write, and he prepared his income tax returns for the taxable years. However, he could tolerate the wearing of such lenses only for brief periods (but not every day) because they produced severe pain and caused corneal ulcers and infection. Purulent material would accumulate in such lenses. . . Petitioner has been abnormally preoccupied with his difficulties of vision. He suffered considerable pain in his eyes, and he was obsessional and delusional with respect to them. He has been emotionally disturbed and mentally ill for many years, including the years in controversy. He was psychotic, and did not have normal contact with reality; he had paranoid thoughts with regard to his. own family. He had a schizophrenic personality. ${ }_{48}^{48}$

Furthermore, the court found that the taxpayer had been indicted on charges of wilful evasion of federal income taxes for the years 1951, 1952, 1954 and 1955, but had not been brought to trial for the reason that upon psychiatric examination the taxpayer had. been found to be so mentally incompetent as to be unable to understand the nature of the proceedings against him or to properly assist counsel in the preparation of his defense; and that upon the Commissioner's motion, the Tax Court case was continued pending. appointment of a special guardian ad litem to prosecute the case on behalf of the taxpayer.

In this factual situation, the Commissioner, on brief, argued that fraud had been shown by the substantial and continued pattern of understatement of income, by the great disparity between reported and unreported income, by virtue of petitioner's actions in filing the amended return during the investigation, and by virtue of petitioner's education and financial activities. ${ }^{49}$ In essence, the Commissioner argued that the pattern of understatement taken together with the other matters of record was sufficient to establish a wilful intent to evade tax. Moreover, with respect to the taxpayer's defense of insanity, the Commissioner argued:

The only evidence proffered related to the alleged mental incompetency. ... Even ... if it did establish that petitioner was mentally incompetent during the crucial year it is without significance for, except insofar as an impairment of mind might deprive the taxpayer of the capacity to form the fraudulent intent, petitioner's incompetency or lack

488 T.C. No. 28 , at 7.

${ }^{\circ}$ Reply Brief for Commissioner, pp. 39-43. Emmanuel Hollman, 38 T.C. No. 28 (1962). 
of it, can have no relationship to the propriety or impropriety of respondent's assertion of the 50 per cent additions to tax for fraud.

....

It is the respondent's position that petitioner must show by the clear preponderance of the evidence that each and every time petitioner prepared and filed his returns for 1951 to 1955, inclusive, he suffered from a mental disorder which totally deprived him of the capacity to understand the nature of his actions. 50

In reply to petitioner's argument that there was no evidence that petitioner had the mental capacity to formulate a fraudulent intent, the Commissioner stated that the affiction must negate petitioner's mental capacity to formulate a fraudulent intent, and that petitioner's assertions, relevant to a criminal proceeding, had no application to the civil fraud case. The Commissioner argued that the test of incompetency was a showing of: "The ability to know the nature, character and effect of one's transactions .... The capacity to consent to simple contract has been equated with the capacity to form and entertain the intent necessary for commission of civil fraud." 51

In the face of this argument, and the strong factual pattern upon which the court could easily have found fraud, it did not do so, purporting to rely upon the Commissioner's failure to carry his burden of proof. It characterized the Commissioner's argument on understatement as an argument that understatement of income alone was sufficient to prove fraud. Conceding that this pattern of understatement was strong evidence of fraud, the court held that the psychiatric testimony cast serious doubt upon the charge of fraud. In addition, the court pointed to the taxpayer's incapacity to stand trial in the criminal proceedings, the necessity to continue the Tax Court case for appointment of a special guardian ad litem, the testimony of the taxpayer's psychiatrists and an independent psychiatrist, and the severity of the taxpayer's psychosis. The court also weighed the evidence of the taxpayer's participation in intricate financial transactions and his astuteness, both of which were inconsistent with the taxpayer's claim of incompetency. The significant portions of the opinion with respect to fraud were the court's statements that:

Petitioner's own testimony ... displayed an astuteness and awareness of matters that make it difficult to say that his mental condition was responsible for the understatements of income. ... [W] Wile we are not

\footnotetext{
${ }^{50}$ Ibid.

${ }^{6}$ Ibid.
} 
fully satisfied that the false returns were a product of mental disease, the psychiatric testimony leaves us with such troubling doubts that we cannot find that fraud has been proved in this case. ${ }^{.22}$

After opinion, the taxpayer filed a motion for further hearing, requesting the court to reopen the record for the sole purpose of showing, by newly discovered evidence, that certain unidentified bank deposits were not income. At the hearing on petitioner's motion, the Commissioner moved to reopen the fraud issue, to the extent that evidence pertinent to this bank deposit bore upon the fraud issue. To this limited extent, the fraud issue was reconsidered by the court. The court, however, upon reconsideration adhered to its position that there was no fraud, stating as follows:

As to the fraud issue, the Court had some doubts at the conclusion of the original hearing, but resolved them in petitioner's favor in view of the burden of proof. These doubts were perhaps somewhat enhanced by the more recent hearing on the newly discovered evidence, but considering the record as a whole, we are still of the opinion that fraud has not been proved by the requisite clear and convincing evidence. ${ }^{53}$

While the matter of fraud is essentially factual, in an area involving the relationship of insanity to civil fraud, certain inferences and implications may be drawn from the court's opinion in Emanuel Hollman. These implications relate to the test of insanity applied and the act to which it must relate.

The definition of civil fraud, cited above, indicates that the capacity to commit the fraudulent act, with its overtones of malice and wrongdoing, closely approximates specific criminal intent. The cases decided in the Tax Court to date involving the defense of insanity do not clearly indicate whether the specific intent required is that of mentally harbouring the calculated fraudulent design, or merely lack of the legal capacity to sign and understand the federal income tax return. Some clue may be provided by the opinion of the Tax Court in the Hollman case. There the court in its opinion stated: "The evidence before us indicated that the petitioner was suffering from a severe psychosis ... and while we are not fully satisfied that the false returns were a product of mental disease ...." W4 Whether the use of the word "product" was calcu-

\footnotetext{
8238 T.C. No. 28 , at 9.

s3 Emanuel Hollman, 1962 P-H TAX CT. MEM. DEC. 962,236 , at 1402 (1962) (on reconsideration).

s4 38 T.C. No. 28 , at 9 . (Emphasis added.)
} 
lated or fortuitous is not clear. If the use of this word were calculated, such use is most significant, for it possibly indicates an embrace of the New Hampshire or Durham rule of criminal responsibility as a test of legal capacity in a civil fraud case. That rule, as expounded by the Supreme Court of New. Hampshire in 1871 was that "the verdict should be not guilty by reason of insanity if the killing was the offspring or product of the mental disease of the defendant . ..."55 This rule, frequently referred to as the "product" rule, has been embraced by the courts of the District of Columbia ${ }^{56}$ and was expressed in the Durham case as follows: "[A]n accused is not criminally responsible if his unlawful act was the product of a mental disease or mental defect." Whether the "product" rule of criminal responsibility has been transferred by the Tax Court to the area of civil fraud is an open question to be resolved by future litigation. By the court's opinion, however, the implication of a hybrid test of criminal responsibility is suggested to determine the capacity of the taxpayer to perpetrate civil tax fraud. Compare the apparent reference to the "right or wrong test" of M'Naghten's Case $^{57}$ in Estate of Clinton $H$. Martin with its possible reference in Hollman to the "product". test. Whether such a criminal test of responsibility is pertinent in the civil tax fraud case appears to be subject to serious question.

Some possible implications of the Emanuel Hollman case may be summarized as follows:

(1) The court may well have indicated that it applied the "product" test of criminal responsibility in arriving at the determination that

\footnotetext{
so State v. Jones, 50 N.H. 369, 398 (1871); State v. Pike, 49 N.H. 399 (1870).

${ }^{60}$ See Durham v. United States, 214 F.2d 862, 874-75 (D.C. Cir. 1954). See also Carter v. United States, 252 F.2d 608 (D.C. Cir. 1957); Fielding v. United States, 251 F.2d 878 (D.C. Cir. 1957); Lyles v. United States, 254 F.2d 725 (D.C. Cir. 1957); Williams v. United States, 250 F.2d 19 (D.C. Cir. 1957); Wright v. United States, 250 F.2d 4 (D.C. Cir. 1957). At this juncture, any inquiry as to why the "product" test may have been considered appropriate by the court may only be answered by sheer speculation or conjecture. One interesting inquiry would be whether the statutory requirement that the Tax Court follow the rules of evidence of the District of Columbia, INT. REv. CODE of $1954, \$ 7453$, led the court to adopt (if indeed it did) the test of criminal responsibility of the District of Columbia. Quaere whether the substantive law of the District of Columbia is applicable.

"7 M'Naghten's Case (1843), 10 Clark and Fin. 200, 8 Eng. Rep. 718, 722. "[T]० establish a defense on the grounds of insanity, it must be clearly proved that, at the time of the committing of the act, the party accused was acting under such a defect of reason from the disease of the mind, as to not know the nature and quality of the act he was doing or if he did know it that he did not know he was doing right from wrong ...."
} 
it was not convinced that the false returns were a product of mental disease.

(2) Consistent with the Commissioner's argument, the court appears to require that the mental disease or defect specifically relate to the execution of the false and fraudulent return, rather than the more general criminal test of lack of responsibility and inability to formulate the specific intent.

(3) This apparently produces a hybrid test: a criminal test of responsibility applied to a question of civil capacity to perform a specific act.

(4) The court accepted by implication the condition of schizophrenia as a condition producing mental incompetency for civil fraud cases.

(5) For the first time, the court apparently attached more weight to expert psychiatric testimony on incompetency than to substantial lay evidence of competency. ${ }^{58}$

Whether these implications will be borne out will require observation, passage of time, and further litigation. It would be conservative to say, however, that this decision of the Tax Court will undoubtedly focus additional attention on the defense of insanity in civil fraud cases.

IV

Some Additional Matters of Consideration in Givil. Fraud Cases Where Insanity is Raised as a Defense by the Taxpayer

Briefly, some matters which must be considered when the defense of insanity is raised in future cases will be: (A) Acquisition of jurisdiction over the incompetent, and the proper party to bring suit; (B) Pleading and proof of insanity and presumptions; and (C) Evidence.

\section{A. Acquisition of Jurisdiction-Proper Parties}

Insanity or incompetency of the party who files the petition in the Tax Court may affect jurisdiction. Therefore, in considering any statutory notice of deficiency, or in determining the capacity of the party to bring the Tax Court action, care should be exercised to see that the statutory notice is addressed to the proper party, and that the petition is filed by the proper party. The Rules of the

\footnotetext{
${ }^{68}$ See notes 77 and 78 , infra.
} 
Tax Court provide only that a case in the Tax Court shall be brought by and in the name of the person against whom the Commissioner determined the deficiency or liability, or by and in the full name of the fiduciary legally entitled to institute a case on behalf of such person. ${ }^{99}$ The general rule, as provided under the Commissioner's regulation, is that if no notice of fiduciary liability (which includes that of a guardian) is filed with the District Director, before the mailing of the statutory notice of deficiency or liability, that a statutory notice of deficiency or liability mailed to a taxpayer will be a sufficient compliance with the requirements of the Code, even though the taxpayer is under a legal disability, and that in such cases, if no petition is filed within the statutory period, the assessment may be made.0

However, it may be envisioned that in some instances the question may arise as to whether the jurisdiction of the Tax Court may attach over one legally incompetent, especially where no guardian has been appointed. In cases where one has not been adjudicated incompetent, the general rule is that jurisdiction may be acquired in civil proceedings by the same process as over a competent person. Where there has been an adjudication of incompetency, it is generally provided that service is to be made upon the committee or guardian. ${ }^{61}$ A real problem may be presented in the case of an adjudication of incompetency, without appointment of a guardian, in view of the rule in some jurisdictions that a judgment obtained against an incompetent is void or voidable. ${ }^{22}$ This matter is beclouded to some extent by the decision of the Tax Court in Sadie $P$. Engel. ${ }^{\text {e3 }}$ There, the petition was signed by the petitioner's father. The son had been in a mental institution for some time prior to the issuance of the statutory notice, but no legal guardian had been appointed. The court concluded that it had no jurisdiction that the son would not be bound by the decision entered therein, and dismissed the petition. That decision may have rested on alterna-

5o Tax Court R. Prac. 6. Compare Rule 4 (d) (2) of the Federal Rules of Civil Procedure which provides that process and summons shall be served upon an incompetent person in the manner prescribed by the law of the state in which service is made for the service of summons or other like process upon any such defendant in an action brought in courts of general jurisdiction of that state.

${ }^{\circ 0}$ Regs. \$ 301,6903-1 (c).

a1 29 AM. JuR. Insane Persons \$115 (1960).

-2 29 AM. JuR. Insane Persons $\$ \$ 117,124,: 27$ (1960).

os 27 P-H Tax Ct. Mem. 229 (1958). 
tive grounds, i.e., simply that the father was not authorized to act, or, that the incompetent without a committee could not authorize the proceedings.

If such a case were presented, the Commissioner may argue that under the broad rules provided under section $301.6903-1$ (c) ${ }^{84}$ of the Regulations, absent proper notice of fiduciary relationship, a statutory notice mailed to an incompetent would be proper and that jurisdiction would attach. Whether the Tax Court could possibly hold that the competency of the party was a matter which went to its jurisdiction, that the situation was analogous to the power of a dissolved corporation to sue or be sued, and that this matter of competency as it relates to jurisdiction was to be determined under the laws of the appropriate state, is problematical. ${ }^{65}$

\section{B. Pleading and Proof of Insanity}

Insanity in a civil case, as in most criminal cases, is an affirmative defense to be plead and proven by the party relying upon such defense. ${ }^{60}$ Of course, it should not be a defense in the sense that it excuses fraud; only in that it negates fraudulent intent. In some jurisdictions, it has been held that the matter of insanity may be raised by a plea of the general issue. ${ }^{67}$ Under the Rules of Practice of the Tax Court, the party filing the petition must assign error even to matters upon which the Commissioner has the burden of proof, but need not set forth statements of the facts in the petition in respect of allegations of error as to which the burden of proof is upon the Commissioner. ${ }^{88}$ However, under Rule 15, the petitioner's reply must set forth any facts upon which the petitioner relies for defense. ${ }^{69}$ The rule would apparently evolve that the matter must be specifically pleaded.

In proving fraud, the Commissioner ordinarily may rely upon the general presumption of sanity, until proof to the contrary is established.70 The quality of the proof necessary on the part of the petitioner is that he must show insanity or incompetency by the

ox See note 59, supra.

of Cf. Wheeler's Peachtree Pharmacy, Inc., 35 T.C. 177 (1960); Sadie P. Engel, 27 P-H Tax Ct. Mem. 229 (1958).

oo 29 AM. Jur. Insane Persons $\S \S 114,130,131$ (1960).

or 29 AM. JUR. Insane Persons $\$ 131$ (1960).

8 Tax Court R. Prac. 7 (c) (ii) (d), (e).

- Tax Court R. Prac. 15 (b).

${ }^{70}$ U.S. v. Cain, 298 F.2d 934 (7th Cir. 1962). 
clear preponderance of the evidence. ${ }^{71}$ If it is concluded that the petitioner has met this burden and the Commissioner then assumes the burden of going forward with the evidence on the issue of insanity, he may resort to lay witnesses, expert witnesses, and to the entire record to show sanity such as is necessary to show that the taxpayer harboured the requisite fraudulent intent.

\section{Evidence}

While the Government is not required to match the taxpayer expert for expert, ${ }^{72}$ positive psychiatric testimony in support of the Government's or the taxpayer's position and as an aid on crossexamination will in many cases be essential to presentation of the parties' cases. One possible source of an expert witness, especially if there has been a prior criminal case, would be the psychiatrist who may have been appointed by the district court to determine the taxpayer's competency to understand the nature of the criminal case and to assist in his own defense. ${ }^{73}$ Is there any hindrance to his testimony at trial? While the statutory authority for such examination expressly provides that the information obtained by the psychiatrist is inadmissible in criminal proceedings, nothing whatsoever is said in that statute as to admissibility of the results of examination in any civil proceeding. ${ }^{74}$ An objection by the taxpayer to the admissibility of evidence of such prior examination under the statutory doctor-patient privilege of the District of Columbia may be expected. ${ }^{75}$ A very significant decision relating to this point was made in Taylor $v$. United States, ${ }^{78}$ where the defendant was committed to a mental institution by the district court for special examination as to competency to stand trial. He was found competent by a staff psychiatrist and tried. On trial of the issue of insanity at the time of the crime, the testimony of the staff psychiatrist as to the sanity of the defendant was admitted over an objection based upon the doctor-patient privilege. The court of appeals re-

\footnotetext{
${ }^{71}$ Cf. Brosnan v. Brosnan, 294 Fed. 1004 (D.C. Cir. 1924); United States v. Peelle Co., 137 F. Supp. 905 (E.D.N.Y. 1956).

72 See note 69, supra.

7318 U.S.C. $\$ 4244$ (1958). Criminal proceedings would be instituted under $\$ 7201$ of the Internal Revenue Code of 1954 which is the criminal sanction comparable to the civil fraud penalty provided under $\$ 6653$ (b), supra. Of necessity the factual background of each case would be essentially similar.

"Ibid.

${ }^{75}$ D.C. CODE ANN. $\$ 14-308$ (196I).

7. 222 F.2d 398 (D.C. Cir. 1955).
} 
versed, holding such testimony inadmissible and concluding that the statute prohibiting the testimony was to be literally construed in favor of exclusion and in protection of the patient-psychiatrist relationship. However, the facts showed that the government psychiatrist had only examined the witness in connection with daily rounds and had never been employed as the man's physician or psychiatrist. While the court of appeals found a professional relationship to exist and construed the examination to have been treatment, on the presentation of such facts in some future proceeding an especially strong argument could be made that the relationship was one only of examination, not of treatment, so that the evidence obtained would be admissible. ${ }^{77}$ Under section 14-308 of the District of Columbia Code, the privilege relates to disclosures made during treatment, but not to those made in examination. The Taylor case was a criminal proceeding, with consequent more stringent rules of evidence. It is apparent that in a civil matter in the Tax Court, the Taylor case may not be considered binding on the court in an evidentiary sense.

In addition to expert testimony, the testimony of lay witnesses appears most important. In fact, the importance of lay witnesses to testify as to the mental condition of the taxpayer can probably not be too heavily emphasized, in view of the decisions of the United States District Court for the Southern District of New York in the Peelle cases. ${ }^{18}$ There, the court accepted the testimony and opinion of lay witnesses as to defendant's insanity, and rejected the testimony of the defendant's five qualified psychiatrists to the effect that the defendant was incompetent. Also note the importance of the evidence of lay witnesses on the activities of the taxpayer indicating sanity in the Hollman case, as well as in other cases where the issue of insanity was raised. ${ }^{79}$ The testimony of such lay witnesses and their opinions as to sanity are admissible in the District of Columbia, and hence in the Tax Court. ${ }^{80}$ However, prior to establishing the lay witnesses' opinion as to the taxpayer's sanity, the lawyer must be careful to lay a predicate showing that the layman

\footnotetext{
77 Catoe v. United States, 131 F.2d 16 (D.C. Cir. 1942).

${ }^{70}$ United States v. Peelle, 159 F. Supp. 45 (E.D.N.Y. 1958); United States v. Peelle Co., 137 F. Supp. 905 (E.D.N.Y. 1956).

79 See notes 32 and 69 , supra.

${ }^{80}$ Life Ins. Co. v. Merrimon, 35 A.2d 828 (D.C. Mun. Ct. App.). See also note 55 supra.
} 
had a good opportunity to observe the taxpayer, an acquaintanceship with the taxpayer, frequent observation, and clearness of observation. In short, the lay witness must have sufficient facts on which to base his opinion, and the opinion must relate to the date of the event at issue. ${ }^{81}$ Such testimony in a fraud case may usually be expected through the witnesses whose testimony is pertinent to prove the fraud items, if the contact of such witnesses with the taxpayer were sufficiently close to be probative.

In addition to these matters, the competency of the taxpayer's own testimony may be affected by the plea of insanity. A real problem demonstrating the care which must be exercised before pleading the defense of insanity is the importance of the taxpayer's own testimony in countering or establishing fraud. Some reasons indicating this importance to the Commissioner are that the taxpayer is adverse, and that any admissions on the stand may bind the taxpayer. Of importance to both parties is the fact that he is frequently the only party competent to identify many of the documents involved, or the only party fully familiar with the pertinent facts.

However, if the taxpayer is mentally incompetent, it does not appear that his testimony is acceptable in the Tax Court for all purposes. While at common law an incompetent was not admissible to be sworn as a witness, the present general rule is that the derangement or defect, in order to disqualify the witness, must be such as to substantially negative trustworthiness upon the specific subject of the testimony and that the witness must be able to apprehend the obligation of an oath. ${ }^{82}$ However, this general rule is apparently qualified in the District of Columbia, with respect to an incompetent, to the extent that, in any civil action against a person legally incapable of testifying or against his committee, no judgment or decree shall be rendered in favor of the adverse party founded on the uncorroborated testimony of an agent, servant, or employee of the adverse party, as to any transaction, declaration or admission of the incapable person. ${ }^{83}$ Whether this provision has applicability to Tax Court proceedings does not appear to have yet been decided.

\footnotetext{
${ }^{81}$ DeBruin v. DeBruin, 90 App. D.C. 236, 195 F.2d 763 (1952); Annot., 40 A.L.R. 2d 153 (1955).

\$2 Wigmore, Evidence $\$ 492$ (3d ed. 1940); District of Columbia v. Armes, 107 U.S. 519 (1882).

BI D.C. CODE ANN. $\S 14-302$ (1961). Whether this provision has literal application "- 'ax Court proceedings does not appear to have been decided in a reported decision.
} 
As a matter of limited relief from the foregoing provision, the District of Columbia Code also provides that the prior testimony of an insane person given at a time when he was competent to testify may be given in evidence in any trial in relation to the same subject matter; and that in such case, the adverse party may testify in opposition thereto. ${ }^{84}$ This latter provision appears especially important in a civil fraud case, as there may well have been a prior criminal trial at a time when the taxpayer was competent. Moreover, another possibility of using the incompetent's testimony would be to establish that it was given by the taxpayer, even if incompetent, during a lucid interval, as testimony during such lucid interval is competent testimony. The party seeking admission, however, has the burden of proof to establish existence of the lucid interval. ${ }^{85}$ Thus, as the taxpayer's testimony is usually important to both parties, real care must be observed to see that the plea of insanity does not render his testimony incompetent.

\section{V}

\section{CoNCLUSION}

Emanuel Hollman apparently contains several important implications which must be considered in prosecuting any civil fraud case where the defense of insanity is raised. These implications, discussed in detail above, afford some indication of a test of insanity in a civil fraud case, the act to which it must relate, and a form of medical insanity recognized by the Tax Court as having legal significance in tax matters. These implications, however, are probably only temporary. The real significance of the case, is that it focuses attention on this very unusual defense in a civil fraud case, thus presenting a relatively new set of problems to be resolved by the court.

\footnotetext{
84 D.C. Code ANN. §14-303 (1961).

${ }^{88} 1$ Bouv. LAw Dict. 2057 (1914).
} 